\title{
Chemical speciation of metals in unpolluted soils of different types: Correlation with soil characteristics and an ANN modelling approach
}

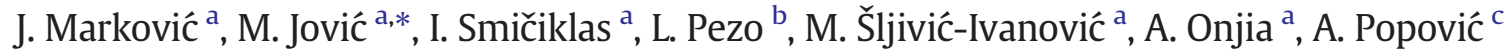 \\ a Vinča Institute of Nuclear Sciences, University of Belgrade, P. O. Box 522, 11000 Belgrade, Serbia \\ ${ }^{b}$ Institute of General and Physical Chemistry, University of Belgrade, 11000 Belgrade, Serbia \\ c The Faculty of Chemistry, University of Belgrade, Studentski trg 12-16, 11000 Belgrade, Serbia
}

\section{A R T I C L E I N F O}

Article history:

Received 30 November 2015

Revised 23 February 2016

Accepted 2 March 2016

Available online 4 March 2016

\section{Keywords:}

Uncontaminated soil

Soil properties

Sequential extraction

Element distribution

Pattern recognition techniques

Artificial neural network

\begin{abstract}
A B S T R A C T
The distribution of elements in soil fractions affects their mobility and availability and thus their potential beneficial or harmful impact on ecosystems, biota and humans. Different mineralogical and chemical characteristics of soil influence elemental distribution. In the present study, chemical speciation of macro and micro elements ( $\mathrm{Al}$, $\mathrm{Fe}, \mathrm{Mn}, \mathrm{K}, \mathrm{Cd}, \mathrm{Cr}, \mathrm{Cu}, \mathrm{Li}, \mathrm{Ba}, \mathrm{Ni}, \mathrm{Pb}$ and $\mathrm{Zn}$ ) in unpolluted soils of different types, collected from the territory of the Republic of Serbia, were analysed by sequential extraction procedure. The impact of the physicochemical soil properties on the content, distribution, mobility and availability of elements was investigated. Principal component analysis was employed for the evaluation and characterization of the experimental data, understanding of the relationships between soil properties and the distribution, affiliation and connection of the elements. Finally, an artificial neural network (ANN) model was developed to explore the applicability of this approach for the prediction of the elemental distribution based on soil properties. Good agreement between the model and the experimental results implied that the ANN could be considered as a useful tool for control and prediction purposes.
\end{abstract}

(c) 2016 Elsevier B.V. All rights reserved.

\section{Introduction}

Elements in soil are present in different levels, which reflect natural differences between soil types and consequences of soil use and pollution. The effects and functions that certain soil elements exert on living organisms range from essential to toxic. An essential element may also be a risk factor if present in inadequate amounts, i.e., concentrations higher than optimal are associated with toxicity while lower ones with nutritional deficiencies. It is generally accepted that the total content of an element in soil is not necessarily related to potential risks (Kelepertzis et al., 2015) and that the total element concentrations cannot provide necessary information on an bioavailability of element (Abollino et al., 2011; Sungur et al., 2014). Mobility and availability depend on the reactivity and binding behaviour of an element with the components of the soil matrix (Abollino et al., 2011). Several studies have investigated the relationship between soil properties and metals distribution (e.g., de Matos et al., 2001; Luz et al., 2014; Sungur et al., 2014), but mixed results were found mainly due to the different mineralogical and chemical characteristics of soils.

The sequential extraction method is a useful instrument to gain information on the bioavailability of elements. One of the most accepted and commonly used is the Tessier extraction scheme (Tessier et al.,

\footnotetext{
* Corresponding author at: University of Belgrade, Vinča Institute of Nuclear Sciences, P. O. Box 522, Belgrade, Serbia.

E-mail address: mjovic@vinca.rs (M. Jović).
}

1979). To date, numerous modifications of the basic procedure have been developed (Alvarez et al., 2006; Arcega-Cabrera et al., 2009; Lucho-Constantino et al., 2005; Riba et al., 2002; Torres and Auleda, 2013; Yu et al., 2000), whereby all of them presume a decrease in element mobility and availability along the extraction sequence. The modified Tessier methods, including the one adopted in this study, usually include alteration of the experimental conditions used for the fifth extraction phase. Namely, instead of total mineralization, which involves the use of $\mathrm{HClO}_{4}$ and $\mathrm{HF}$, extraction by other strong acids and their mixtures are applied. Consequently, the residual fraction becomes "pseudoresidual". Furthermore, one additional stage has frequently been added to the Tessier scheme, to enable the determination of a water-soluble fraction of elements (Adhikari et al., 2005; Kabata-Pendias, 2001; Lucho-Constantino et al., 2005; Smičiklas et al., 2015). Using a sequential extraction method, comprehensive information can be obtained on the origin, mode of occurrence, biological and physicochemical availability, mobilization and transportation of elements (Sungur et al., 2014). In environmental impact studies, it is more important to determine element speciation patterns in soil than to assess their total pedogenic concentrations (Sungur et al., 2014).

The sequential extraction method results in a large amount of experimental data, especially when coupled to multi-element analytical techniques, such as ICP OES, which enable the simultaneous elemental analysis of a large number of samples. Moreover, the physicochemical properties of the considered soil matrix (such as particle size distribution, $\mathrm{pH}$ value, total carbon content, inorganic carbon content, total 
organic carbon, cation exchange capacity) significantly contribute to increasing the data set. Accordingly, due to simultaneous consideration of many parameters, multivariate chemometric techniques are very helpful in the visualization and interpretation of sequential extraction results (Giacomino et al., 2011).

Various multivariate statistical techniques have been employed for the evaluation and characterization of environmental data (e.g., Amiri, 2014; Giacomino et al., 2011). Principal component analysis (PCA) is a commonly used multivariate method for data reduction (the number of explanatory variables is lowered by using specific factors), but it is also used for classification and discrimination of the samples. These factors explain the major variation within the data in order to make the components more interpretable. In the last decade, PCA became accepted and used by a large number of research groups engaged in the analyses of uncontaminated, contaminated and agricultural soils (Abollino et al., 2006, 2002a, 2002b; Pérez and Valiente, 2005; Tokalioğlu and Kartal, 2003; Tokalioğlu et al., 2004).

The basic idea of the present research was to establish the correlations between soil physicochemical properties of soils and the distribution of a large set of elements in order to explore the predictability of their distribution based on available soil properties. In such cases, nonlinear models are more suitable due to complexity of the matrix. Artificial neural network (ANN) models are recognized as good modelling tools since they provide the solution to the problems from a set of experimental data, and are capable of handling complex systems with nonlinearities and interactions between decision variables (e.g., Almeida, 2002; Kashani et al., 2014). The developed empirical models should provide a reasonable fit to experimental data and successfully predict element mobility in different soil types.

The specific objectives of the study were: $(i)$ to determine the distribution of twelve elements (minor $\mathrm{Cd}, \mathrm{Cr}, \mathrm{Cu}, \mathrm{Li}, \mathrm{Ba}, \mathrm{Ni}, \mathrm{Pb}$ and $\mathrm{Zn}$, and major Al, Fe, Mn and $\mathrm{K}$ ) in samples of different soil types having considerably different physicochemical properties (i.e., the content of sand, silt and clay fraction, $\mathrm{pH}$, cation exchange capacity (CEC), total organic carbon (TOC), content of $\mathrm{CaCO}_{3}, \mathrm{P}_{2} \mathrm{O}_{5}$ and $\mathrm{K}_{2} \mathrm{O}$ ); (ii) to estimate the influence of soil properties on the content, distribution, mobility and availability of the elements; (iii) to apply a pattern recognition technique (PCA) on the data (used as descriptors) to characterize and differentiate among the observed samples; and (iv) to test the applicability of an ANN for the development of a mathematical model which would provide a reasonable fit of experimental data on the distribution of the elements based on the available soil properties, for control and prediction purposes.

\section{Materials and methods}

\subsection{Soil sampling and characterization}

As the study aimed to establish correlations between soil physicochemical properties and distribution of elements, samples were selected based on their diversity in terms of their essential characteristics.
The investigated samples $\left(\mathrm{S}_{1}-\mathrm{S}_{8}\right)$, representing eight different soil types, were collected from various localities in the Republic of Serbia, from a depth $0-25 \mathrm{~cm}$. A composite sample of each soil was prepared from five subsamples. The soils used in this study were characterized as described in detail in a previously published article (Smičiklas et al., 2015). The soil types were determined and denoted according to the World reference base for soil resources (FAO, 2006): $S_{1}-$ Humic Fluvisol, $\mathrm{S}_{2}-$ Fluvisol, $\mathrm{S}_{3}$ - Eutric Cambisol, $\mathrm{S}_{4}-$ Mollic Leptosol, $\mathrm{S}_{5}-$ Stagnosol, $\mathrm{S}_{6}-$ Leptosol, $\mathrm{S}_{7}-$ Dystric Cambisol and $\mathrm{S}_{8}-$ Rendzic Leptosols. The descriptive statistics of physicochemical properties of examined soil types (Table 1 ) show wide ranges of soil $\mathrm{pH}, \mathrm{CEC}, \mathrm{TOC}$, texture and nutrient content.

\subsection{Sequential extraction}

Soil samples were subjected to sequential extraction following a modified Tessier procedure (Tessier et al., 1979). Whereby, the examined elements were partitioned into six operationally defined fractions: water soluble $\left(F_{0}\right)$, exchangeable $\left(F_{1}\right)$, bound to carbonates $\left(F_{2}\right)$, bound to $\mathrm{Fe}-$, Mn-oxides $\left(\mathrm{F}_{3}\right)$, bound to organic matter $\left(\mathrm{F}_{4}\right)$ and residual $\left(\mathrm{F}_{5}\right)$. The sequential extraction procedure applied in this study, which was previously described in detail by Smičiklas et al. (2015), was conducted in triplicate for each sample, and the mean of the three concentration values determined for the investigated elements in each fraction were reported.

\subsection{Analytical technique for the determination of the elements}

The contents of the elements were determined using an inductively coupled plasma optical emission spectrometer (ICP-OES) model iCAP 6500 Duo (Thermo Scientific, United Kingdom). Radial view measurements were applied for $\mathrm{Al}$, Fe and $\mathrm{K}$, and axial for $\mathrm{Zn}$, $\mathrm{Ba}, \mathrm{Cd}, \mathrm{Cr}, \mathrm{Cu}, \mathrm{Li}, \mathrm{Mn}, \mathrm{Ni}$ and $\mathrm{Pb}$. The axial view provides better LODs (limit of detections) while the radial view is preferred for higher element concentrations. This instrument is an Echelle-type spectrometer covering the $166-847 \mathrm{~nm}$ range equipped with an RACID86 charge injection detector.

Determination was realized using external calibrations with matrix matched standards prepared from single stock solutions of $1000 \mathrm{ppm}$ (Merck, Germany). Stock solutions were mixed into multi-standard working solutions according to their concentrations in the soil samples. Working standard solutions were matrix matched according to each extraction solution that was applied. Correlation coefficients for calibration curves were greater than 0.9999. For quality assurance, ICP multi-element standard solution VI (Merck, Germany) was used. Quality control (QC) was performed using the ACCU standard MES 21-1 as a QC standard, blank samples, standard reference material (SRM 2711) and triplicate analyses of each sample. The QC standard was measured at a frequency of every 10 analytical samples with recovery limits $\pm 10 \%$. Three replicates of the SRM 2711 - Montana Soil (National Institute of Standards \& Technology) were digested

Table 1

Descriptive statistics of physicochemical properties of the investigated soil types.

\begin{tabular}{|c|c|c|c|c|c|c|c|c|c|c|}
\hline & Sand $^{a}$ & Silt $^{\mathrm{b}}$ & Clay $^{c}$ & $\mathrm{CaCO}_{3}{ }^{\mathrm{d}}$ & $\mathrm{pH}_{\mathrm{KCl}}$ & $\mathrm{pH}_{\mathrm{H} 2 \mathrm{O}}$ & $\mathrm{CEC}^{\mathrm{e}}$ & $\mathrm{TOC}^{\mathrm{d}}$ & $\mathrm{P}_{2} \mathrm{O}_{5}{ }^{\mathrm{f}}$ & $\mathrm{K}_{2} \mathrm{O}^{\mathrm{f}}$ \\
\hline Mean & 32.2 & 30.8 & 37.1 & 2.90 & 5.46 & 7.05 & 32.03 & 2.28 & 9.69 & 28.19 \\
\hline $\mathrm{SD}^{\mathrm{g}}$ & 8.3 & 9.4 & 8.3 & 5.24 & 1.45 & 0.91 & 8.62 & 1.30 & 10.16 & 11.60 \\
\hline Minimum & 24.8 & 12.2 & 22.7 & 0 & 3.40 & 5.50 & 22.50 & 0.82 & 0.01 & 8.80 \\
\hline Maximum & 48.8 & 43.8 & 50.1 & 11.7 & 6.90 & 8.00 & 47.80 & 4.75 & 30.00 & 43.00 \\
\hline Range & 24.0 & 31.6 & 27.4 & 11.7 & 3.50 & 2.50 & 25.30 & 3.93 & 29.99 & 34.20 \\
\hline
\end{tabular}

a $>0.02 \mathrm{~mm}, \%$.

b $0.02-0.002 \mathrm{~mm}, \%$.

c $<0.002 \mathrm{~mm}, \%$.

d \%.

e $\mathrm{cmol} \mathrm{kg}^{-1}$.

${ }^{f} \mathrm{mg} \cdot 100 \mathrm{~g}^{-1}$.

g Standard deviation. 
in a microwave accelerated reaction system model MARS 5 (CEM Corporation, USA) according to the US EPA method 3051 A (US EPA, 2007) and the digestate was diluted with Milli-Q deionized water $(18 \mathrm{M} \Omega$ ). Recovery ratios between the certified and the analytical values for SRM 2711 ranged from 87.2 to $112.8 \%$ for the investigated elements.

\subsection{Statistical methods}

To classify the different soil samples, PCA was applied by Eigenvalue decomposition of the correlation matrix of the obtained experimental data set in such a way that the first component contained the largest possible variance. In this manner, maximum separation between the clusters of parameters was achieved. PCA was applied in order to comprehend the relations of the obtained results, specifically the correlation between the content of the elements and the soil fractions, as well as between the soil properties and the total content of the investigated elements. In addition, linear correlation coefficients were calculated to understand the relationships between the inter-element fractions and the element-soil properties.

Data were analysed by Statistica software (Data Analysis Software System, v.10.0, StatSoft, Inc., Tulsa, OK, USA). According to the recommendation of StatSoft Statistica, the experimental database was randomly divided into three groups for the development of the ANN model: training data $-60 \%$, cross-validation $-20 \%$ (used to test the performance of the network while training) and testing data $-20 \%$ (used to examine the network generalization capability). A multi-layer perceptron model (MLP) consisting of three layers (input, hidden and output) was used in this study because it is the most common, flexible and general-purpose kind of ANN (Arsenović et al., 2013). The MLP neural network learns using an algorithm called "backpropagation". The Levenberg-Marquardt algorithm has been proved to be the fastest and particularly adapted for networks of moderate size. During this iterative process, the input data are repeatedly presented to the network (Grieu et al., 2011).

\section{Results and discussion}

3.1. Relations between pseudo-total metal concentrations and soil physicochemical properties

The pseudo-total amounts, the sum of the individual fractions, $\sum=F_{0}+F_{1}+F_{2}+F_{3}+F_{4}+F_{5}$, of each investigated element in the eight soil samples are given in Table 2 . Of the investigated metals, concentrations of $\mathrm{Fe}$ and $\mathrm{Al}$ were commonly the highest, followed by $\mathrm{K}$ and $\mathrm{Mn}$. Heavy metals ( $\mathrm{Cd}, \mathrm{Cr}, \mathrm{Cu}, \mathrm{Ni}, \mathrm{Pb}, \mathrm{Zn}, \mathrm{Ba}$ ), as well as Li were detected in a wide range of concentrations $(0.0750-529 \mu \mathrm{g} / \mathrm{g})$.

The PCA of pseudo-total element contents and physicochemical properties of the soil samples showed that the first two principal

Table 2

Pseudo-total concentrations $\left(\mu \mathrm{g} \mathrm{g}^{-1}\right.$ ) of the examined elements in different soil samples $\left(\mathrm{S}_{1}-\mathrm{S}_{8}\right)$.

\begin{tabular}{lllllllll}
\hline & \multicolumn{7}{l}{ Pseudo-total element concentrations in $\mu \mathrm{g} \mathrm{g}^{-1}$ dry weight } \\
\cline { 2 - 8 } & $\mathrm{S}_{1}$ & $\mathrm{~S}_{2}$ & $\mathrm{~S}_{3}$ & $\mathrm{~S}_{4}$ & $\mathrm{~S}_{5}$ & $\mathrm{~S}_{6}$ & $\mathrm{~S}_{7}$ & $\mathrm{~S}_{8}$ \\
\hline $\mathrm{Al}$ & 1413 & 1419 & 1853 & 1879 & 2214 & 1669 & 1851 & 1532 \\
$\mathrm{Ba}$ & 78.5 & 83.2 & 326 & 100 & 86.8 & 56.8 & 65.6 & 114 \\
$\mathrm{Cd}$ & 0.189 & 0.164 & 0.192 & 0.201 & 0.149 & 0.158 & 0.0750 & 0.133 \\
$\mathrm{Cr}$ & 43.5 & 40.9 & 62.5 & 24.4 & 45.0 & 501 & 20.7 & 24.6 \\
$\mathrm{Cu}$ & 54.8 & 45.9 & 47.4 & 31.3 & 31.7 & 141 & 40.1 & 33.4 \\
$\mathrm{Fe}$ & 11,811 & 14,461 & 23,572 & 14,101 & 11,448 & 24,354 & 12,336 & 11,977 \\
$\mathrm{~K}$ & 4417 & 1811 & 5059 & 3480 & 1472 & 609 & 1760 & 4396 \\
$\mathrm{Li}$ & 13.7 & 15.1 & 22.1 & 12.9 & 12.8 & 15.6 & 10.6 & 18.4 \\
$\mathrm{Mn}$ & 216 & 704 & 1837 & 1247 & 2408 & 1380 & 217 & 675 \\
$\mathrm{Ni}$ & 69.0 & 73.7 & 62.1 & 22.6 & 61.4 & 529 & 18.4 & 28.1 \\
$\mathrm{~Pb}$ & 22.6 & 34.6 & 44.4 & 21.7 & 35.6 & 27.5 & 10.0 & 19.7 \\
$\mathrm{Zn}$ & 56.6 & 53.2 & 54.7 & 35.6 & 31.5 & 34.9 & 28.3 & 36.9 \\
\hline
\end{tabular}

components (PCs) explained $57.00 \%$ of the total variance in the original data (Fig. 1). The $\mathrm{PC}_{1}$ contributed $29.17 \%$, and the $\mathrm{PC}_{2} 27.83 \%$ to the total variance. The contents of $\mathrm{Cr}$ (which contributed $7.9 \%$ of total variance), $\mathrm{Cu}(7.9 \%), \mathrm{Fe}(16.9 \%)$ and $\mathrm{Ni}$ (11.7\%) exhibited positive scores according to $\mathrm{PC}_{1}$, while the clay content $(11.5 \%)$ and $\mathrm{K}_{2} \mathrm{O}$ content $(9.7 \%)$ exhibited negative influences on $\mathrm{PC}_{1}$. The contents of $\mathrm{Cd}(8.3 \%), \mathrm{Li}(7.4 \%), \mathrm{Zn}$ (9.4\%) and silt fraction (9.0\%), together with $\mathrm{pH}_{\mathrm{KCl}}(10.0 \%)$ and $\mathrm{pH}_{\mathrm{H} 2 \mathrm{O}}$ (12.8\%), exhibited positive influences on $\mathrm{PC}_{2}$, whereas $\mathrm{Al}$ (7.0\%) and the sand fraction content (10.1\%) exhibited negative influences on $\mathrm{PC}_{2}$. The Pearson's coefficients $(r)$ were calculated and the obtained correlations, statistically significant at the $p<0.01, p<0.05$ and $p<0.10$ levels, are given in Table 3.

Soil sample of Leptosol $\left(\mathrm{S}_{6}\right)$ stands out with the highest pseudo-total concentrations of $\mathrm{Cr}, \mathrm{Cu}, \mathrm{Fe}$ and $\mathrm{Ni}$, and with the lowest for $\mathrm{Ba}$ and $\mathrm{K}$ (Table 2, Fig. 1). This soil type is also characterized by the highest values of TOC (4.75\%) and the lowest values of $\mathrm{P}_{2} \mathrm{O}_{5}\left(0.01 \mathrm{mg} \cdot 100 \mathrm{~g}^{-1}\right), \mathrm{K}_{2} \mathrm{O}$ $\left(8.8 \mathrm{mg} \cdot 100 \mathrm{~g}^{-1}\right)$ and clay content $(22.7 \%)$ in relation to the other observed soil types (Smičiklas et al., 2015). $\mathrm{S}_{6}$ distinguished itself by having both the highest and the lowest deviations in terms of the obtained concentration variations $(\mathrm{Cr}, \mathrm{Cu}, \mathrm{Fe}, \mathrm{K}$ and $\mathrm{Ni}$ ) in the examined soil samples (Table 2). The sample of Eutric Cambisol $\left(\mathrm{S}_{3}\right)$ is characterized by a low content of $\mathrm{CaCO}_{3}$ and the highest pseudo-total concentrations of $\mathrm{Ba}, \mathrm{K}, \mathrm{Li}$ and $\mathrm{Pb}$. The highest pseudo-total concentrations of $\mathrm{Al}$ and $\mathrm{Mn}$ were found in soil $\mathrm{S}_{5}$ (Stagnosol) which exhibited the smallest content of $\mathrm{Fe}$ in relation to the other investigated soils, and also a low content of $\mathrm{CaCO}_{3}$. Dystric Cambisol $\left(\mathrm{S}_{7}\right)$ was the soil with the highest content of sand (48.8\%) and the lowest content of $\mathrm{Cd}, \mathrm{Cr}, \mathrm{Li}, \mathrm{Ni}, \mathrm{Pb}, \mathrm{Zn}$, silt, $\mathrm{pH}, \mathrm{TOC}$ and $\mathrm{CaCO}_{3}$. Soil sample $\mathrm{S}_{1}$ (Humic Fluvisol) is characterized by the highest pseudo-total concentrations of $\mathrm{Zn}$, $\mathrm{pH}$ value, $\mathrm{P}_{2} \mathrm{O}_{5}$ and $\mathrm{K}_{2} \mathrm{O}$ contents, and the lowest content of $\mathrm{Al}$ and $\mathrm{Mn} ; \mathrm{S}_{2}$ (Fluvisol) by the highest silt content and $\mathrm{pH}$ value, and the lowest CEC; and $\mathrm{S}_{4}$ (Mollic Leptosol) by the highest content of $\mathrm{Cd}$ and the lowest values for $\mathrm{Cu}$ and $\mathrm{CaCO}_{3}$.

The significant correlations between $\mathrm{Cu}-\mathrm{Cr}, \mathrm{Ni}-\mathrm{Cr}$ and $\mathrm{Ni}-\mathrm{Cu}(0.98$, $1.00,0.98$, at $p<0.01$, respectively; Table 3 ) indicate that these metals have a common origin in the natural soils and appear together independently of soil type. The high correlation, but at a lower level of significance $(p<0.05$ ), was also obtained for the $\mathrm{Fe}-\mathrm{Cr}$ pair (Table 3$)$. The positive correlation between $\mathrm{Li}$ and $\mathrm{Ba}\left(0.81, p^{<} 0.05\right)$ suggests their natural origin and interrelationship in different types of soil. A similar conclusion could be made for the pair Al-Mn, based on the obtained significant correlation at the $p<0.05$ level (Table 3 ).

Considering the textural properties of soil, a negative correlation $(-0.72$ at $p<0.05)$ was found between the sand content and the pseudo-total concentration of $\mathrm{Cd}$ in all soil samples. This indicates that an increased sand content is accompanied by reduced $\mathrm{Cd}$

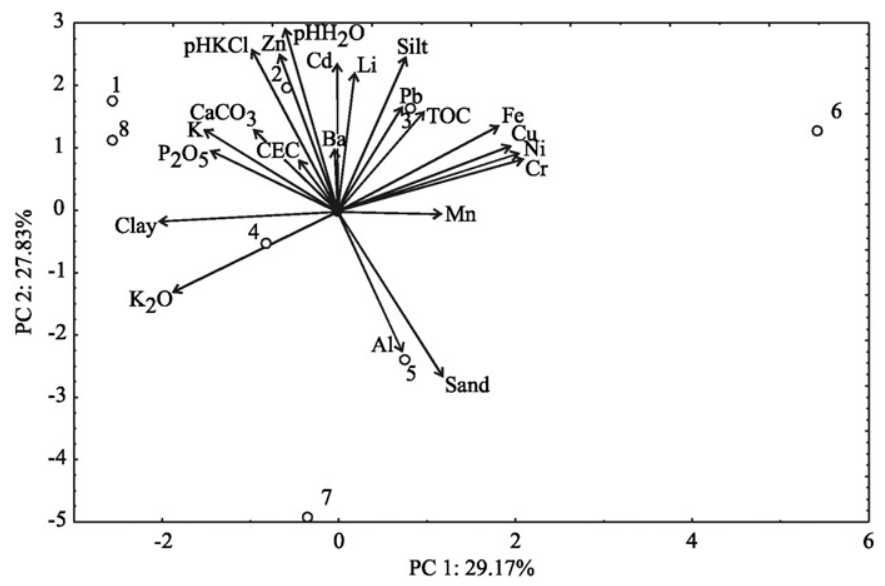

Fig. 1. Biplot of correlated pseudo-total element contents and physicochemical properties of the investigated soil types. 
Table 3

Correlation matrix for the pseudo-total concentrations of different elements and physicochemical parameters of the examined soil types.

\begin{tabular}{|c|c|c|c|c|c|c|c|c|c|c|c|c|c|c|c|}
\hline & $\mathrm{Ba}$ & $\mathrm{Cu}$ & $\mathrm{Fe}$ & K & $\mathrm{Li}$ & Mn & $\mathrm{Ni}$ & $\mathrm{Pb}$ & Sand & Clay & $\mathrm{CaCO}_{3}$ & $\mathrm{pH}_{\mathrm{KCl}}$ & $\mathrm{pH}_{\mathrm{H} 2 \mathrm{O}}$ & TOC & $\mathrm{K}_{2} \mathrm{O}$ \\
\hline $\mathrm{Al}$ & 0.17 & -0.22 & 0.01 & -0.24 & -0.20 & $0.74^{*}$ & -0.12 & 0.19 & 0.48 & -0.15 & -0.58 & $-0.83^{*}$ & $-0.83^{*}$ & -0.33 & 0.04 \\
\hline $\mathrm{Ba}$ & & -0.20 & 0.50 & $0.64^{\mathrm{x}}$ & $0.81^{*}$ & 0.40 & -0.23 & $0.64^{x}$ & -0.23 & 0.21 & -0.11 & -0.12 & -0.08 & -0.27 & -0.30 \\
\hline $\mathrm{Cd}$ & & 0.06 & 0.32 & 0.44 & 0.40 & 0.33 & 0.07 & 0.58 & $-0.72^{*}$ & -0.08 & -0.14 & 0.49 & 0.53 & 0.27 & -0.06 \\
\hline $\mathrm{Cr}$ & & $0.98^{+}$ & $0.71^{*}$ & -0.53 & 0.10 & 0.20 & $1.00^{+}$ & 0.09 & 0.29 & $-0.72^{*}$ & -0.24 & -0.05 & 0.12 & $0.76^{*}$ & $-0.71^{*}$ \\
\hline $\mathrm{Cu}$ & & & $0.71^{x}$ & -0.47 & 0.10 & 0.05 & $0.98^{+}$ & 0.06 & 0.27 & $-0.69^{x}$ & -0.23 & 0.02 & 0.19 & $0.76^{*}$ & $-0.67^{x}$ \\
\hline $\mathrm{Fe}$ & & & & -0.06 & 0.60 & 0.37 & $0.69^{x}$ & 0.51 & 0.14 & -0.56 & -0.28 & -0.11 & 0.02 & 0.37 & $-0.85^{+}$ \\
\hline K & & & & & 0.57 & -0.15 & -0.54 & 0.12 & -0.61 & $0.78^{*}$ & 0.11 & 0.40 & 0.33 & -0.09 & 0.35 \\
\hline $\mathrm{Mn}$ & & & & & & & 0.18 & $0.72^{*}$ & 0.00 & -0.38 & -0.33 & -0.44 & -0.32 & -0.01 & -0.40 \\
\hline $\mathrm{Ni}$ & & & & & & & & 0.11 & 0.26 & $-0.73^{*}$ & -0.21 & -0.02 & 0.16 & $0.77^{*}$ & $-0.71^{x}$ \\
\hline Sand & & & & & & & & & & -0.36 & -0.51 & $-0.83^{*}$ & $-0.82^{*}$ & -0.16 & -0.14 \\
\hline $\mathrm{pH}_{\mathrm{KCl}}$ & & & & & & & & & & & & & $0.96^{+}$ & 0.37 & 0.09 \\
\hline
\end{tabular}

Unmarked correlations are not statistically significant.

+ Statistically significant at $p<0.01$ level.

* Statistically significant at $p<0.05$ level.

$x$ Statistically significant at $p<0.10$ level.

concentrations, regardless of the other soil characteristics. A negative relation between total $\mathrm{Cd}$ and sand content was also determined for 69 sites in New Zealand (Reiser et al., 2014). The statistically significant correlations obtained in this study also indicated that an increased content of the clay fraction was associated with decreased contents of $\mathrm{Cr}$ and $\mathrm{Ni}(-0.72$ and -0.73 at $p<0.05$, respectively) and an increased $\mathrm{K}$ concentration $(0.78$ at $p<0.05)$.

Among the other relations, it was found that the soil $\mathrm{pH}$ decreased with increasing concentrations $\mathrm{Al}$ and sand contents, while the content of $\mathrm{K}_{2} \mathrm{O}$ was negatively correlated with the concentrations of $\mathrm{Cr}$ and $\mathrm{Fe}$ (Table 3). Pearson's correlation analysis also indicated that the soil TOC was positively correlated with the amounts of $\mathrm{Cr}, \mathrm{Cu}$ and $\mathrm{Ni}(0.76$, 0.76 and 0.77 , respectively, at $p<0.05$ ).

\subsection{Relations between metal distribution and physicochemical properties} of the soil

Mobilities of elements largely depend on the types of bonds by which they are associated with the soil components. The first two fractions of the applied sequential extraction $F_{0}$ (water soluble) and $F_{1}$ (exchangeable) constitute the available forms of elements. $F_{2}$ (bound to carbonates) and $\mathrm{F}_{3}$ (bound to iron and manganese oxides) phases are potentially mobile, but not readily available under natural conditions. Finally, the last two fractions $\mathrm{F}_{4}$ (bound to organic matter) and $\mathrm{F}_{5}$ (residual) constitute unavailable pools of elements (Abollino et al., 2011). The hitherto correlations between soil characteristics and element distribution, referred to several elements and/or soil samples (Ashraf et al., 2012; Guo et al., 2005; Navas and Lindhorfer, 2005; Sipos et al., 2014) and, therefore, this study aimed at extending the database.

The different patterns of metal partitioning in soil, being the function of metal and soil properties, are demonstrated in Fig. 2. PCA was performed to analyse possible relationships between soil types and the distribution of elements in different phases. The rotation of PCs was executed by the Varimax method with Kaiser normalization. The PCA showed that the first PCs explained $64.05 \%$ of the total variance in the original data, Fig. 3. The $\mathrm{PC}_{1}$ contributed $44.33 \%$, and the $\mathrm{PC}_{2}$ $19.72 \%$ to the total variance. The contents of $\mathrm{Al}$ (which contributed $14.1 \%$ of total variance), $\mathrm{Cr}$ (7.9\%), $\mathrm{Cu}(7.9 \%), \mathrm{Fe}$ (16.9\%), K (8.2\%), Li (13.3\%), Ni (8.3\%), Zn (13.0\%), exhibited negative scores according to the $\mathrm{PC}_{1}$. The contents of $\mathrm{K}(14.5 \%), \mathrm{Li}(8.8 \%)$ and $\mathrm{Zn}(11.1 \%)$ showed a positive influence on the evaluation of the $\mathrm{PC}_{2}$, while the content of $\mathrm{Mn}(26.5 \%)$ and $\mathrm{Pb}(19.3 \%)$ exhibited negative influences on the $\mathrm{PC}_{2}$ (Fig. 3). The Pearson's correlation coefficients between the content of the investigated elements in different soil fractions are presented in Table 4.

The grouping of Cd with the samples related to Phase 1 (samples No. 9-16), Fig. 3, indicated that this element was mainly bound to the exchangeable phase $\left(F_{1}\right)$ in most of the examined soil samples. The obtained pseudo-total Cd concentrations in the present study were in agreement with the average concentration of $\mathrm{Cd}$ in the Earth's crust $(\sim 0.2 \mu \mathrm{g} / \mathrm{g})$ and with the background Cd level in surface soils ( ${ }^{\circ} 1 \mathrm{mg} \mathrm{kg}^{-1}$ ) (Gleyzes et al., 2002; Petrovic et al., 2009). Cadmium was identified as the most mobile of the investigated metals, with up to $60.5 \%$ in the exchangeable fraction. A high mobility of Cd was detected in other uncontaminated soil samples (Dimović et al., 2013), as well as in contaminated soil around a mining area (He et al., 2013). Pueyo et al. (2003) investigated the distribution of a large number of elements ( $\mathrm{Al}, \mathrm{Ca}, \mathrm{Fe}, \mathrm{Mg}, \mathrm{Mn}, \mathrm{As}, \mathrm{Bi}, \mathrm{Cd}, \mathrm{Cu}, \mathrm{Pb}, \mathrm{Tl}$ and $\mathrm{Zn}$ ) in contaminated soil and found that $\mathrm{Cd}$ was the most mobile. Due to the high Cd mobility and availability, its increased concentration in soil may cause long-term risks to the ecosystem, biota and humans, and hence, $\mathrm{Cd}$ belongs to the group pollutants that are of major interest in bioavailability studies listed by the US Environmental Protection Agency.

The interconnection of Phase 3 (samples No. 25-32) with $\mathrm{Mn}$ and $\mathrm{Pb}$ indicate that these elements in soils are primarily linked to iron and manganese oxides. Logically, $\mathrm{Mn}$ as one of the main contributors in soil occurs mainly in the oxide fraction ( 44 to $81 \%$ ). The remaining Mn content is distributed between the other phases, in amounts which obviously depend on soil type. The mobility of Mn in soils is extremely sensitive to soil conditions, such as acidity, wetness, organic matter content, biological activity (Nadaska et al., 2012). Generally, low pH values favour the reduction of insoluble manganese oxides, resulting in increased manganese mobility, while at soil $\mathrm{pH}$ values above $6, \mathrm{Mn}$ is efficiently bound to organic matter, oxides and silicates, resulting in decreased Mn solubility. In addition, Mn availability is high in soils with low content of organic matter (Nadaska et al., 2012). This was confirmed by the present results, in which the most mobile Mn was found in samples Dystric Cambisol $\left(\mathrm{S}_{7}\right)$, Stagnosol $\left(\mathrm{S}_{5}\right)$ and Eutric Cambisol $\left(\mathrm{S}_{3}\right)$, characterized by both low $\mathrm{pH}$ and low TOC content. Mn was found in the readily available phase for biogeochemistry cycles in the ecosystems $\left(F_{1}\right)$ and potentially bioavailable phase $\left(F_{2}\right)$, up to $16 \%$ and $11 \%$, respectively, for certain soil types. A similar distribution of $\mathrm{Mn}$ in soil, with the highest content in $\mathrm{F}_{3}$, was also obtained by Petrovic et al. (2009); Walna et al. (2010) and Navas and Lindhorfer (2005). Pb was also mainly associated to Fe-, Mn-oxide fraction (32-66\%), followed by the oxidizable $\left(\mathrm{F}_{4}\right)$ phase $(17-45 \%)$ and the residual phase (13-27\%). Negligible Pb concentrations were found in fractions $F_{0}$ and $F_{1}$, except for Dystric Cambisol $\left(S_{7}\right)$, in which the labile $F_{1}$ phase represents $11 \%$ of the pseudo-total concentration. Abollino et al. (2002a) and Guo et al. (2005) reported that Pb was mostly associated with the residual phase, while Sarkar et al. (2014) found that the major geochemical phase for $\mathrm{Pb}$ was the Fe-, Mn-oxides phase, followed by the residual and the oxidizable phases, as was the case in the present study. Pb was found to have a high affinity for soil Fe-oxides. This was confirmed by Cornu et al. (2005), who reported that Pb was able to 

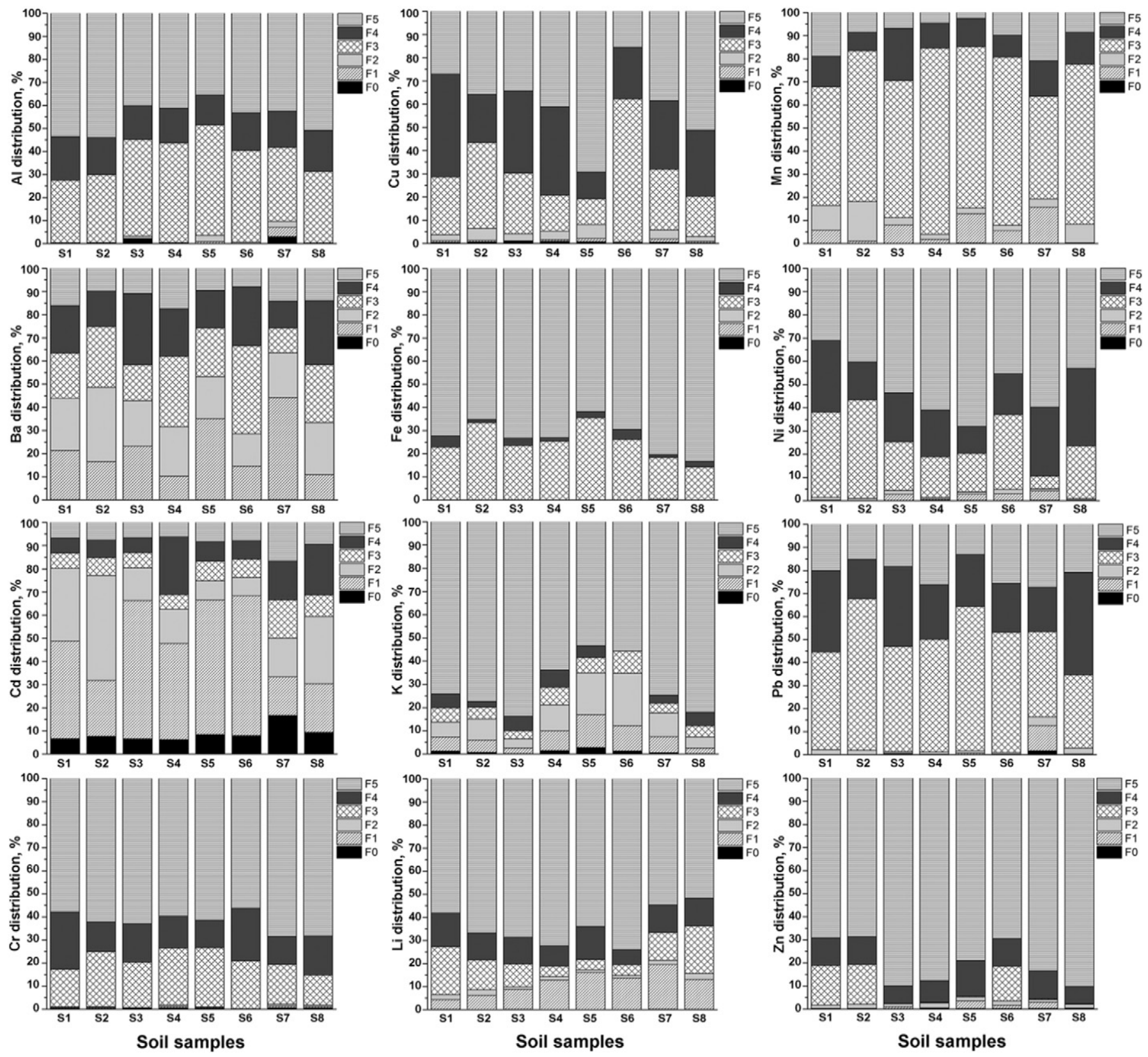

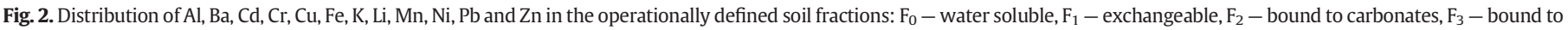
$\mathrm{Fe}-$, Mn-oxides, $\mathrm{F}_{4}$ - bound to organic matter, $\mathrm{F}_{5}$ - residual.

form stable hydroxide and carbonate complexes which are preferentially bound to the (slightly) positively charged Fe-oxide surfaces. $\mathrm{Pb}$ in the examined soil samples had a low potential mobility $\left(0 \%\right.$ for $\mathrm{F}_{0}$ and around $2 \%$ for the $F_{1}$ and $F_{2}$ phases, on average) and, generally speaking, it could be considered as a relatively immobile element. The exception was sample $\mathrm{S}_{7}$ with $13 \%$ of potentially mobile $\mathrm{Pb}\left(\mathrm{F}_{0}+\mathrm{F}_{1}\right)$. Given that $\mathrm{S}_{7}$ was characterized by the lowest pseudo-total concentration of $\mathrm{Pb}$ compared with the other soil types, the higher mobility was more likely influenced by specific soil characteristics than some source of contamination.

The high correlations between $\mathrm{K}, \mathrm{Zn}$, $\mathrm{Li}$ and Fe $(\mathrm{Zn}-\mathrm{Li}=0.94$, Fe$\mathrm{Li}=0.91, \mathrm{~K}-\mathrm{Zn}=0.89, \mathrm{Fe}-\mathrm{Zn}=0.88, \mathrm{~K}-\mathrm{Li}=0.81$ and $\mathrm{Fe}-\mathrm{K}=$ 0.73 at $p<0.01$; Table 4) and their association with samples of Phase 5 (samples No. 41-48) on the bioplot PCA diagram, Fig. 3, indicate a similar distribution of these elements in the soil phases, with the highest amount in $\mathrm{F}_{5}$. In all soil samples, $\mathrm{Zn}$ was the most abundant in the residual fraction (69-90\%). Negligible concentrations of this element were found in phase $F_{0}, F_{1}$ and $F_{2}$, indicating its low mobility. The abundance of $\mathrm{Zn}$ in $\mathrm{F}_{4}$ phase of all samples ranged from 7 to $15 \%$. An inappreciable amount of $Z n$ was found in phase $F_{3}$ except for in samples $S_{1}, S_{2}$ and $S_{6}$, in which the abundance was $15-17 \%$. A difference in the $\mathrm{Zn}$ distribution among the various soil types was evidenced by Sarkar et al. (2014). The association of $\mathrm{Zn}$ with the Fe-, Mn-oxide phase may be linked to the high stability constants of Zn oxides (Abdu, 2010). Fe-oxides adsorb considerable quantities of $\mathrm{Zn}$ and may also occlude $\mathrm{Zn}$ in the lattice structures (Sarkar et al., 2014). Li and $\mathrm{K}$ also existed mainly in the residual phase (52-74\% and 53-84\%, respectively). High content in $\mathrm{F}_{5}$ could primarily be linked to their natural geochemical origin and their association with the soil matrix. Between $4-19 \%$ and $2-14 \%$ of the extracted $\mathrm{Li}$ and $\mathrm{K}$, respectively, were associated with the exchangeable phase and thus were quite labile and easily available. Presence of Li and $\mathrm{K}$ in the remaining phases varies significantly depending on the soil type, except in $F_{0}$, in which negligible concentrations were found. In the available literature, it was difficult to find an adequate study to compare the 


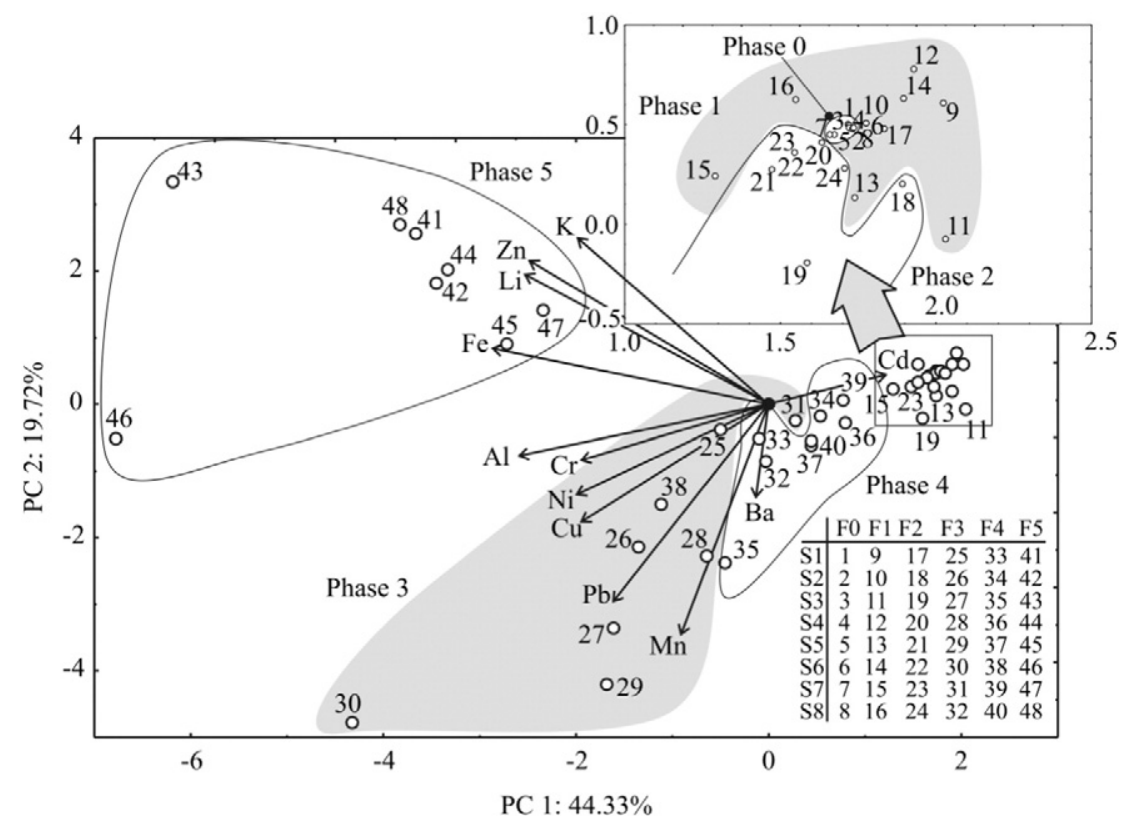

Fig. 3. Biplot of the correlated element contents in different fractions $\left(F_{0}, F_{1}, F_{2}, F_{3}, F_{4}\right.$ and $\left.F_{5}\right)$ in the investigated soil samples $\left(S_{1}-S_{8}\right)$.

distribution of these two elements. Finally, Fe is a soil macro element present mainly in the residual phase (62-83\%). In all soil types, the Fe distribution followed the order: $\mathrm{F}_{5}{ }^{>} \mathrm{F}_{3}{ }^{>} \mathrm{F}_{4}$. The high percentages of $\mathrm{Fe}$ in the hardly accessible or inaccessible element pools confirmed its interconnection with the soil matrix.

A high correlation was also obtained between $\mathrm{Fe}$ and $\mathrm{Al}$ (Table 4). $\mathrm{Al}$ was primarily distributed between the $\mathrm{F}_{3}(27-48 \%)$ and $\mathrm{F}_{5}(35-54 \%)$ phases, and in the F4 phase (13-19\%). Insignificant concentrations of both $\mathrm{Fe}$ and $\mathrm{Al}$ were found in phases $\mathrm{F}_{0}-\mathrm{F}_{2}$. The obtained results for the $\mathrm{Fe}$ and $\mathrm{Al}$ distributions in the soil samples were in good agreement with those of several reported studies (e.g., Abollino et al., 2002a; Navas and Lindhorfer, 2005; Sarkar et al., 2014).

The high correlations between $\mathrm{Cr}, \mathrm{Ni}$ and $\mathrm{Cu}$ at $p<0.01$ (Table 4) indicate their similar speciation in the investigated soils. The highest levels of $\mathrm{Cr}$ were found in the $\mathrm{F}_{5}$ phase of all soils, and the highest levels of $\mathrm{Ni}$ and $\mathrm{Cu}$ were determined in this phase of the majority of the investigated soils. The dominant proportion of $\mathrm{Ni}$ and $\mathrm{Cr}$ found in the residual phase is in agreement with the results of other studies (Abollino et al., 2002a; Guo et al., 2005; Sarkar et al., 2014). Ni and Cr are, apart from the $\mathrm{F}_{5}$, present in $\mathrm{F}_{3}$ (6-42\% for $\mathrm{Ni}$ and $13-26 \%$ for $\mathrm{Cr}$ ) and $\mathrm{F}_{4}$ (12-33\% for $\mathrm{Ni}$ and $12-25 \%$ for $\mathrm{Cr}$ ) phases. In soil samples $\mathrm{S}_{3}, \mathrm{~S}_{5}, \mathrm{~S}_{6}$ and $\mathrm{S}_{7}$, Ni was present in $\mathrm{F}_{1}(\sim 3 \%)$, which represents its easily releasable content. $\mathrm{Cu}$ was distributed between the $\mathrm{F}_{3}, \mathrm{~F}_{4}$ and $\mathrm{F}_{5}$ phases, with no similar pattern, indicating that the type of soil plays an important role in the distribution and mobility of $\mathrm{Cu}$. Copper has an ionic radius close to that of $\mathrm{Fe}^{3+}$ and thus, it could be incorporated into the structure of crystalline Fe-oxides. Furthermore, the high stability constants of $\mathrm{Cu}$ complexes with organic matter enable $\mathrm{Cu}$ binding to lipids, proteins, and carbohydrates, while the high affinity of clay minerals for $\mathrm{Cu}$ incorporation explains its presence in the residue (Martinez and McBride, 1998; Sarkar et al., 2014). No statistically significant correlations were found between $\mathrm{Ba}$ and the other examined elements. Ba was evenly distributed between phases $F_{1}, F_{2}, F_{3}, F_{4}$ and $F_{5}$, with a negligible concentration in phase $\mathrm{F}_{0}$, in all the examined soil types.

As a final point, to clarify in what manner soil properties affect the mobility of examined elements, the Pearson's correlation coefficients were calculated (Table 5). The distribution of the majority of elements, in one or more soil fractions, was in correlation with the specific soil characteristics, whereas the patterns of Ba and Mn partitioning could not be connected with any of the investigated soil properties at the desired level of statistical significance.

The partitioning of the macro-elements Fe and K was significantly correlated to the soil texture, i.e., to the content of clay. With the increased percentage of clay fraction in the soil, the Fe found in Fe-, Mnoxide phase decreased, while the $\mathrm{K}$ concentration increased in the most stable fractions $\mathrm{F}_{4}$ and $\mathrm{F}_{5}$. The total content of $\mathrm{K}$ in soil generally

Table 4

Correlation matrix for the element contents in different phases of the soil samples $(n=48)$.

\begin{tabular}{|c|c|c|c|c|c|c|c|c|c|c|}
\hline & $\mathrm{Cd}$ & $\mathrm{Cr}$ & $\mathrm{Cu}$ & $\mathrm{Fe}$ & K & $\mathrm{Li}$ & $\mathrm{Mn}$ & $\mathrm{Ni}$ & $\mathrm{Pb}$ & $\mathrm{Zn}$ \\
\hline $\mathrm{Al}$ & $-0.42^{+}$ & $0.37^{*}$ & $0.51^{+}$ & $0.79^{+}$ & $0.53^{+}$ & $0.66^{+}$ & $0.56^{+}$ & $0.39^{+}$ & 0.67 & $0.66^{+}$ \\
\hline $\mathrm{Ba}$ & $0.26^{\mathrm{x}}$ & -0.08 & 0.07 & -0.02 & 0.04 & 0.04 & $0.31^{*}$ & -0.07 & $0.35^{*}$ & -0.05 \\
\hline $\mathrm{Cd}$ & & -0.18 & $-0.28^{x}$ & $-0.31^{*}$ & -0.16 & -0.18 & -0.13 & -0.18 & $-0.34^{*}$ & $-0.26^{x}$ \\
\hline $\mathrm{Cr}$ & & & $0.53^{+}$ & $0.60^{+}$ & 0.09 & $0.45^{+}$ & 0.12 & $0.96^{+}$ & 0.22 & $0.34^{*}$ \\
\hline $\mathrm{Cu}$ & & & & $0.45^{+}$ & 0.18 & $0.29^{*}$ & $0.33^{*}$ & $0.71^{+}$ & 0.48 & $0.34^{*}$ \\
\hline $\mathrm{Fe}$ & & & & & $0.73^{+}$ & $0.91^{+}$ & 0.17 & $0.57^{+}$ & $0.37^{*}$ & $0.88^{+}$ \\
\hline K & & & & & & $0.81^{+}$ & -0.11 & 0.04 & 0.07 & $0.89^{+}$ \\
\hline $\mathrm{Li}$ & & & & & & & -0.08 & $0.39^{+}$ & 0.18 & $0.94^{+}$ \\
\hline $\mathrm{Mn}$ & & & & & & & & 0.20 & 0.79 & -0.12 \\
\hline $\mathrm{Ni}$ & & & & & & & & & $0.31^{*}$ & $0.31^{*}$ \\
\hline $\mathrm{Pb}$ & & & & & & & & & & 0.17 \\
\hline
\end{tabular}

Unmarked correlations are not statistically significant.

+ Statistically significant at $p<0.01$ level.

* Statistically significant at $p<0.05$ level.

$\times$ Statistically significant at $p<0.10$ level. 
Table 5

Pearson's coefficients and $p$-values for the statistically significant correlations $\left(p^{<} 0.05\right)$ obtained between soil properties and elements in various fractions of the soils.

\begin{tabular}{|c|c|c|c|c|}
\hline Element & Phase & Property & $r$ & $p$ \\
\hline \multirow[t]{8}{*}{$\mathrm{Al}$} & \multirow[t]{2}{*}{$\mathrm{F}_{1}$} & Sand & 0.846 & 0.008 \\
\hline & & Silt & -0.802 & 0.017 \\
\hline & $\mathrm{F}_{2}$ & $\mathrm{pH}$ & -0.921 & 0.001 \\
\hline & $\mathrm{F}_{2}$ & TOC & 0.770 & 0.026 \\
\hline & \multirow[t]{2}{*}{$\mathrm{F}_{3}$} & Clay & -0.741 & 0.035 \\
\hline & & TOC & 0.748 & 0.033 \\
\hline & $\mathrm{F}_{4}$ & TOC & 0.786 & 0.021 \\
\hline & \multirow[t]{2}{*}{$\mathrm{F}_{5}$} & Clay & -0.716 & 0.046 \\
\hline \multirow[t]{5}{*}{$\mathrm{Cr}$} & & TOC & 0.760 & 0.029 \\
\hline & \multirow[t]{2}{*}{$\mathrm{F}_{2}$} & TOC & -0.742 & 0.034 \\
\hline & & CEC & -0.712 & 0.048 \\
\hline & \multirow[t]{2}{*}{$\mathrm{F}_{3}$} & Clay & -0.725 & 0.042 \\
\hline & & TOC & 0.736 & 0.037 \\
\hline $\mathrm{Cu}$ & $\mathrm{F}_{4}$ & TOC & 0.762 & 0.028 \\
\hline \multirow[t]{2}{*}{$\mathrm{Fe}$} & $\mathrm{F}_{3}$ & Clay & -0.843 & 0.009 \\
\hline & $\mathrm{F}_{4}$ & Clay & 0.753 & 0.031 \\
\hline \multirow[t]{3}{*}{ K } & $\mathrm{F}_{5}$ & Clay & 0.761 & 0.028 \\
\hline & \multirow[t]{2}{*}{$\mathrm{F}_{2}$} & $\mathrm{CaCO}_{3}$ & 0.866 & 0.005 \\
\hline & & $\mathrm{pH}$ & 0.746 & 0.034 \\
\hline $\mathrm{Li}$ & $\mathrm{F}_{3}$ & CEC & 0.751 & 0.032 \\
\hline \multirow[t]{10}{*}{$\mathrm{Cd}$} & \multirow[t]{2}{*}{$\mathrm{F}_{2}$} & Sand & -0.731 & 0.039 \\
\hline & & $\mathrm{pH}$ & 0.811 & 0.015 \\
\hline & \multirow[t]{2}{*}{$\mathrm{F}_{0}$} & Clay & -0.737 & 0.037 \\
\hline & & TOC & 0.724 & 0.042 \\
\hline & \multirow[t]{2}{*}{$\mathrm{F}_{1}$} & Clay & -0.721 & 0.044 \\
\hline & & TOC & 0.730 & 0.04 \\
\hline & \multirow[t]{2}{*}{$\mathrm{F}_{3}$} & Clay & -0.736 & 0.037 \\
\hline & & TOC & 0.772 & 0.025 \\
\hline & $\mathrm{F}_{4}$ & TOC & 0.816 & 0.014 \\
\hline & \multirow[t]{2}{*}{$\mathrm{F}_{5}$} & Clay & -0.754 & 0.031 \\
\hline \multirow[t]{3}{*}{$\mathrm{Ni}$} & & TOC & 0.740 & 0.036 \\
\hline & \multirow[t]{2}{*}{$\mathrm{F}_{1}$} & Sand & 0.859 & 0.006 \\
\hline & & Silt & -0.809 & 0.015 \\
\hline \multirow[t]{5}{*}{$\mathrm{Pb}$} & $\mathrm{F}_{3}$ & Silt & 0.728 & 0.041 \\
\hline & \multirow[t]{2}{*}{$\mathrm{F}_{1}$} & Sand & 0.717 & 0.045 \\
\hline & & $\mathrm{pH}$ & -0.948 & 0 \\
\hline & \multirow[t]{3}{*}{$\mathrm{F}_{2}$} & Sand & -0.786 & 0.021 \\
\hline & & Silt & 0.861 & 0.006 \\
\hline Zn & & $\mathrm{pH}$ & 0.751 & 0.032 \\
\hline
\end{tabular}

increased with increasing clay content (Peverill et al., 1999), which was confirmed by the significant positive correlation found in the present study $\left(0.78, p^{-} 0.05\right.$, Table 3$)$. Furthermore, the observed high stability of $\mathrm{K}$ in the clay-rich soils was in agreement with the previously reported significant positive relationship between non-exchangeable $\mathrm{K}$ and the illite clay content (Rezapour et al., 2009). The mobility of Al was not only strongly related to soil texture, but also to $\mathrm{pH}$, two mutually connected soil properties (Table 3 ). The content of $\mathrm{Al}$ in the most mobile $F_{1}$ phase was positively correlated with the sand and negatively with the silt content. In addition, a negative relationship between soil $\mathrm{pH}$ and the $\mathrm{Al}$ content in $\mathrm{F}_{2}$ was observed, which may be connected with negative correlation linking soil $\mathrm{pH}$ with the pseudo-total content of $\mathrm{Al}\left(-0.83\right.$ at $p^{<} 0.05$; Table 3$)$.

Considering the distribution of the micro-elements, the effects of the soil properties were numerous and complex. The distribution of Li was mostly affected by soil $\mathrm{pH}$ and carbonate content. The correlations were positive, meaning a higher Li content in the $\mathrm{F}_{2}$ fraction of carbonate-rich soils, which also exhibited higher $\mathrm{pH}$ values. The general weak influence of $\mathrm{CaCO}_{3}$ on the distribution of the other elements may be partially ascribed to the lack of carbonates in samples $\mathrm{S}_{3}-\mathrm{S}_{6}$. A similar absence of the effect of carbonate content on the mobility of $\mathrm{Pb}, \mathrm{Cu}, \mathrm{Cr}$,
Zn, As and Sn was registered by Ashraf et al. (2012) in the ex-mining land of Bestari Jaya, Malaysia. The Cd distribution was significantly affected solely in $\mathrm{F}_{2}$ fraction. The $\mathrm{Cd}$ content increased with decreasing sand content, which is in agreement with the negative correlation between the sand content and the pseudo-total concentration of $\mathrm{Cd}$ in various soil types ( -0.72 at $p^{<} 0.05$; Table 3$)$. In contrast, the content of $\mathrm{Cd}$ in $\mathrm{F}_{2}$ was positively correlated with soil $\mathrm{pH}$. The easily available content of $\mathrm{Pb}$ in the $\mathrm{F}_{1}$ fraction largely increased with increasing sand fraction. On the other hand, increasing silt content is associated with stabilization of $\mathrm{Pb}$ through its redistribution from $\mathrm{F}_{1}$ to $\mathrm{F}_{3}$. The increased sand content had a similar effect on the mobility of $\mathrm{Zn}$, given that the $\mathrm{Zn}$ concentration in $F_{1}$ increased, while simultaneously decreased in $F_{2}$, with increasing sand fraction. Soil $\mathrm{pH}$ had an opposing effect, i.e., with increasing $\mathrm{pH}$, the $\mathrm{Zn}$ redistributed from $\mathrm{F}_{1}$ to $\mathrm{F}_{2}$.

The distributions of $\mathrm{Cu}, \mathrm{Cr}$ and Ni were largely affected by the soil TOC and the clay content. The negative correlation between clay content and pseudo-total concentrations of $\mathrm{Cr}, \mathrm{Cu}$ and $\mathrm{Ni}$ was previously observed (Table 3 ). In light of the results presented in Table 5 , the observed trend may be interpreted as a decrease of the $\mathrm{Cr}$ content in $\mathrm{F}_{3}$ and $F_{5}$, a Cu decrease in $F_{3}$, and a reduction in the Ni content in $F_{0}, F_{1}$, $\mathrm{F}_{3}$ and $\mathrm{F}_{5}$. In addition the TOC content also showed a significant correlation with the pseudo-total $\mathrm{Cr}, \mathrm{Cu}$ and $\mathrm{Ni}$ concentrations, but a positive one (Table 3). Thus, the increasing total concentration of the mentioned elements with increasing TOC may be associated with increasing $\mathrm{Cr}$ content in $\mathrm{F}_{2}, \mathrm{~F}_{3}, \mathrm{~F}_{4}$ and $\mathrm{F}_{5}$, the $\mathrm{Cu}$ in $\mathrm{F}_{3}$ and $\mathrm{F}_{4}$, and $\mathrm{Ni}$ in $\mathrm{F}_{0}, \mathrm{~F}_{1}, \mathrm{~F}_{3}, \mathrm{~F}_{4}$ and $F_{5}$. In addition, some stabilization of $\mathrm{Cu}$ with increasing TOC may be an explanation for the observed redistribution from $F_{2}$ to $F_{3}$ and $F_{4}$. The $\mathrm{Cu}$ content in the carbonate fraction was also negatively correlated with the soil CEC.

\subsection{ANN modelling of metal distribution in different soil types}

The Broyden-Fletcher-Goldfarb-Shanno (BFGS) algorithm, implemented in the StatSoft Statistica evaluation routine, was used for the ANN modelling. The optimization procedures to minimize the error function between network and experimental outputs was used during the ANN training cycle (Pezo et al., 2013; Taylor, 2006) and the sum of squares (SOS) was evaluated according to the BFGS algorithm, to accelerate and stabilize the convergence of the results (Basheer and Hajmeer, 2000). The training process was repeated several times in order to obtain the best performance of the ANN, due to a high degree of variability of the parameters. It was accepted that successful training was achieved when the learning and cross-validation curves (SOS vs. training cycles) approached zero. Coefficient of determination $\left(r^{2}\right)$ and SOS were used as parameters to check the performance (i.e., the accuracy) of the obtained ANN.

The optimum number of hidden neurons was chosen upon minimizing the difference between the predicted ANN values and the desired outputs, using SOS during testing as a performance indicator. The employed MLP is marked according to StatSoft Statistica's notation, "MLP" followed by the number of inputs, number of neurons in the hidden layer, and the number of outputs. According to the ANN performance (sum of $r^{2}$ and SOSs for all variables in one ANN), it was determined that the optimal number of neurons in the hidden layer is 7 (network MLP 2-4-12), Table 6.

The goodness-of-fit, between the experimental measurements and model calculated outputs, represented as ANN performance $\left(r^{2}\right.$ between measured and calculated $\mathrm{Al}, \mathrm{Ba}, \mathrm{Cd}, \mathrm{Cr}, \mathrm{Cu}, \mathrm{Fe}, \mathrm{K}, \mathrm{Li}, \mathrm{Mn}, \mathrm{Ni}, \mathrm{Pb}$

Table 6

ANN summary.

\begin{tabular}{|c|c|c|c|c|c|c|c|c|c|c|}
\hline $\begin{array}{l}\text { Network } \\
\text { name }\end{array}$ & $\begin{array}{l}\text { Training } \\
\text { performance }\end{array}$ & $\begin{array}{l}\text { Test } \\
\text { performance }\end{array}$ & $\begin{array}{l}\text { Validation } \\
\text { performance }\end{array}$ & $\begin{array}{l}\text { Training } \\
\text { error }\end{array}$ & $\begin{array}{l}\text { Test } \\
\text { error }\end{array}$ & $\begin{array}{l}\text { Validation } \\
\text { error }\end{array}$ & $\begin{array}{l}\text { Training } \\
\text { algorithm }\end{array}$ & $\begin{array}{l}\text { Error } \\
\text { function }\end{array}$ & $\begin{array}{l}\text { Hidden } \\
\text { activation }\end{array}$ & $\begin{array}{l}\text { Output } \\
\text { activation }\end{array}$ \\
\hline MLP 2-4-12 & 0.783 & 0.795 & 0.853 & 0.110 & 0.140 & 0.180 & BFGS 73 & SOS & Tanh & Logistic \\
\hline
\end{tabular}


Table 7

Coefficients of determination, $r^{2}$, between experimentally measured and ANN outputs, during the training, testing and validation steps.

\begin{tabular}{|c|c|c|c|c|c|c|c|c|c|c|c|c|}
\hline$r^{2}$ & $\mathrm{Al}$ & $\mathrm{Ba}$ & $\mathrm{Cd}$ & $\mathrm{Cr}$ & $\mathrm{Cu}$ & $\mathrm{Fe}$ & $\mathrm{K}$ & $\mathrm{Li}$ & $\mathrm{Mn}$ & $\mathrm{Ni}$ & $\mathrm{Pb}$ & $\mathrm{Zn}$ \\
\hline Training & 0.978 & 0.625 & 0.910 & 0.438 & 0.572 & 0.931 & 0.815 & 0.919 & 0.901 & 0.427 & 0.920 & 0.962 \\
\hline Testing & 0.988 & 0.072 & 0.564 & 0.965 & 0.955 & 0.998 & 0.992 & 0.970 & 0.575 & 0.616 & 0.854 & 0.993 \\
\hline Validation & 0.882 & 0.897 & 0.854 & 0.965 & 0.679 & 0.964 & 0.926 & 0.952 & 0.561 & 0.818 & 0.785 & 0.949 \\
\hline
\end{tabular}

and $\mathrm{Zn}$ ) during the training, testing and validation steps, is given in Table 7.

The ANN models were used to predict the experimental variables ( $\mathrm{Al}, \mathrm{Ba}, \mathrm{Cd}, \mathrm{Cr}, \mathrm{Cu}, \mathrm{Fe}, \mathrm{K}, \mathrm{Li}, \mathrm{Mn}, \mathrm{Ni}, \mathrm{Pb}$ and $\mathrm{Zn}$ ) in the different soil types and phases. The networks were able to predict reasonably well all process outputs for a broad range of the process variables (as seen in Fig. 4, where the experimental measured and ANN model predicted values are presented).

The predicted values were very similar to the desired values in most cases, in terms of the $r^{2}$ value, for the ANN models. The SOS obtained with the ANN models were of the same order of magnitude as the experimental errors for $\mathrm{Al}, \mathrm{Ba}, \mathrm{Cd}, \mathrm{Cr}, \mathrm{Cu}, \mathrm{Fe}, \mathrm{K}, \mathrm{Li}, \mathrm{Mn}, \mathrm{Ni}, \mathrm{Pb}$ and $\mathrm{Zn}$ reported in the literature (Basheer and Hajmeer, 2000; Pezo et al., 2013). The values of $r^{2}$ between experimental and ANN model (MLP 2-4-12) outputs, for $\mathrm{Al}, \mathrm{Ba}, \mathrm{Cd}, \mathrm{Cr}, \mathrm{Cu}, \mathrm{Fe}, \mathrm{K}, \mathrm{Li}, \mathrm{Mn}, \mathrm{Ni}, \mathrm{Pb}$ and $\mathrm{Zn}$ were 0.978 , $0.625,0.910,0.438,0.572,0.931,0.815,0.919,0.901,0.427,0.920$ and 0.962 , respectively, during the training period. Moreover, the means and the standard deviations of the residuals were analysed. The mean of the residuals for the ANN model were 5.90, $-2.88,0.00$, $-4.64,-1.14,-422.99,-7.65,-0.12,-8.04,-3.66,-0.06$ and -0.02 for $\mathrm{Al}, \mathrm{Ba}, \mathrm{Cd}, \mathrm{Cr}, \mathrm{Cu}, \mathrm{Fe}, \mathrm{K}, \mathrm{Li}, \mathrm{Mn}, \mathrm{Ni}, \mathrm{Pb}$ and $\mathrm{Zn}$, respectively, while the standard deviations were 96.65, 18.17, 0.02, 41.01, 11.49, $1675.17,553.68,1.32,225.93,39.21,3.06$ and 3.51, respectively. These results showed a relatively good approximation to a normal distribution around zero with a probability of $95 \%(2 \cdot S D)$, which indicates a good generalization ability of the ANN model for the ranges of the observed experimental values.

The fitting parameters imply that the ANN approach has a significant potential as a tool for the rapid assessment of metal mobility. The improvement in the prediction reliability should be tested in the future by taking into account additional soil parameters (such as mineralogy, specific surface area and porosity, anion exchange capacity (AEC), the type of organic matter). For instance, it could easily be observed from Fig. 4 that the predicted and measured $\mathrm{K}$ concentrations were largely scattered in the region of high concentrations, associated with fraction $\mathrm{F}_{5}$. As clay mineralogy plays an important role in terms of the distribution of the K content (Rezapour et al., 2009), it must be taken into consideration as input data for ANN development. Furthermore, the high concentrations of $\mathrm{Ni}$ and $\mathrm{Cr}$ in sample $\mathrm{S}_{6}$ have a pronounced impact on the fitting results (Fig. 4). Even though $S_{6}$ is an unpolluted soil, some locations in Serbia are recognized as $\mathrm{Ni}$ and $\mathrm{Cr}$ rich (Albanese et al., 2015), and such unusually high concentrations of naturally occurring elements were associated with ophiolite masses and related sedimentary rocks. Therefore, the goodness-of-fit could be enhanced by increasing the total sample size, which would, among others, also contain more extremes.

\section{Conclusions}

This study aimed to provide information on the speciation of $\mathrm{Al}$, Fe, $\mathrm{Mn}, \mathrm{K}, \mathrm{Cd}, \mathrm{Cr}, \mathrm{Cu}, \mathrm{Li}, \mathrm{Ba}, \mathrm{Ni}, \mathrm{Pb}$ and $\mathrm{Zn}$ in different types of unpolluted soil, and establish correlations of metal contents and speciation with soil characteristics. For this purpose, a chemometric approach (PCA and ANN) was employed for the evaluation of the results of sequential extraction analysis. The patterns of metal partitioning were dependent on both metal and soil type. With the exception of $\mathrm{Cd}$ and $\mathrm{Ba}$, these metals were commonly found in the less available fractions $\left(F_{3}, F_{4}\right.$ and $F_{5}$ ). Generally, soil texture and TOC had a predominant impact on the
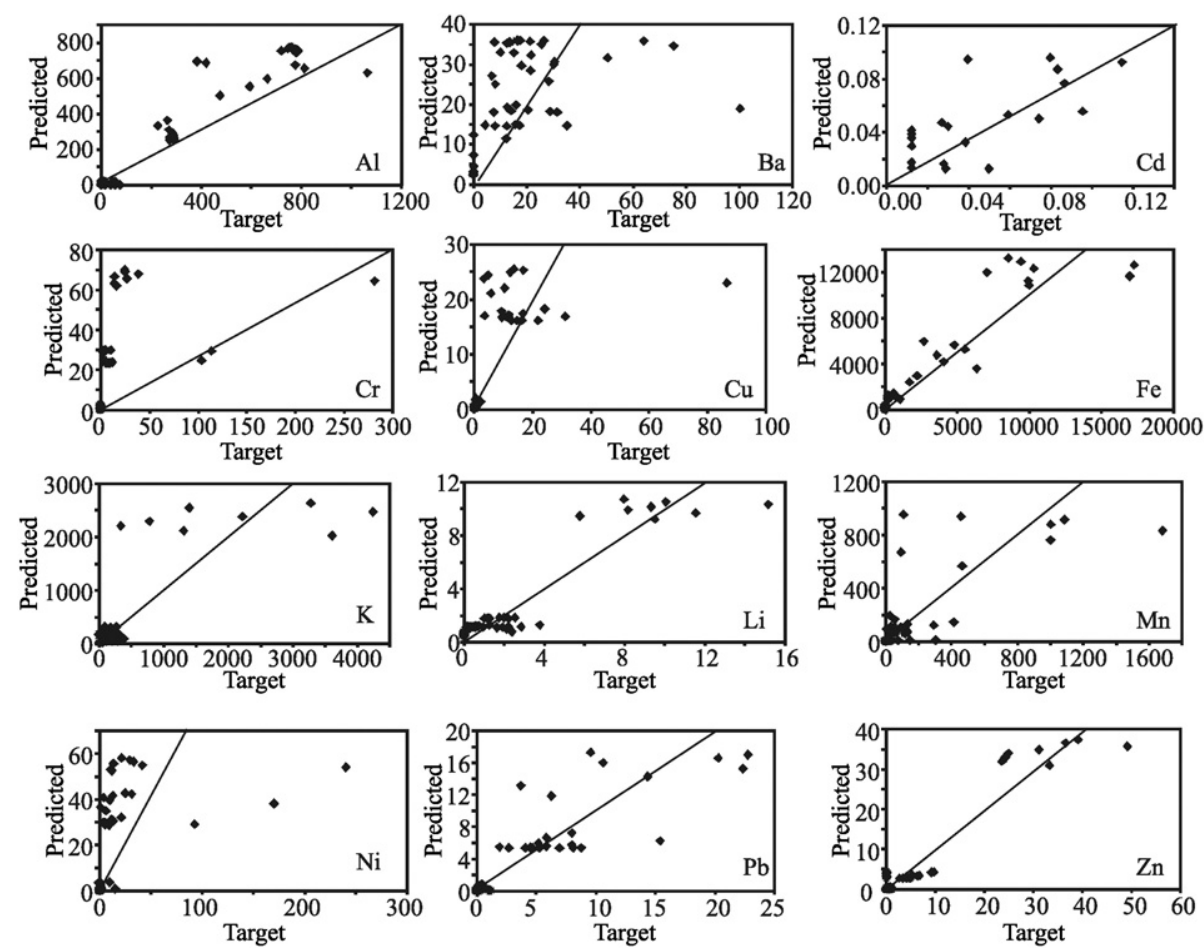

Fig. 4. Experimentally measured and $\mathrm{ANN}$ model predicted values of $\mathrm{Al}, \mathrm{Ba}, \mathrm{Cd}, \mathrm{Cr}, \mathrm{Cu}, \mathrm{Fe}, \mathrm{K}, \mathrm{Li}, \mathrm{Mn}, \mathrm{Ni}, \mathrm{Pb}$, and $\mathrm{Zn}$ in different soil fractions. 
metal contents and speciation. Samples with a higher percentage of sand exhibited increased contents of $\mathrm{Pb}, \mathrm{Zn}$ and $\mathrm{Al}$ in phase $\mathrm{F}_{1}$, which is readily available in the environment. An ANN model was developed in order to predict the complex distribution and mobility of elements in uncontaminated soils based on the known soil properties. High $r^{2}$ values and prediction accuracy of the observed outputs proved the ANN as useful in the prediction of metal (especially $\mathrm{Al}, \mathrm{Cd}, \mathrm{Fe}, \mathrm{K}, \mathrm{Li}$, $\mathrm{Mn}, \mathrm{Pb}$ and $\mathrm{Zn}$ ) mobility in soils with a wide range of characteristics. The obtained relationships are important for a rapid assessment of metal speciation and represent a starting point for analysing mobility changes due to contamination.

\section{Acknowledgement}

This work was supported by the Ministry of Education Science and Technological Development of the Republic of Serbia (Project III43009).

\section{References}

Abdu, N., 2010. Availability, Transfer and Balances of Heavy Metals in Urban Agriculture of West Africa. Kassel University Press GmbH, Kassel, Germany.

Abollino, O., Aceto, M., Malandrino, M., Mentasti, E., Sarzanini, C., Barberis, R., 2002a. Distribution and mobility of metals in contaminated sites. Chemometric investigation of pollutant profiles. Environ. Pollut. 119, 177-193. http://dx.doi.org/10.1016/S02697491(01)00333-5.

Abollino, O., Aceto, M., Malandrino, M., Mentasti, E., Sarzanini, C., Petrella, F., 2002b. Heavy metals in agricultural soils from Piedmont, Italy. Distribution, speciation and chemometric data treatment. Chemosphere 49, 545-557. http://dx.doi.org/10.1016/S00456535(02)00352-1.

Abollino, O., Giacomino, A., Malandrino, M., Mentasti, E., Aceto, M., Barberis, R., 2006. Assessment of metal availability in a contaminated soil by sequential extraction. Water Air Soil Pollut. 173, 315-338. http://dx.doi.org/10.1007/s11270-005-9006-9.

Abollino, O., Malandrino, M., Giacomino, A., Mentasti, E., 2011. The role of chemometrics in single and sequential extraction assays: a review. Anal. Chim. Acta 688, 104-121. http://dx.doi.org/10.1016/j.aca.2010.12.020.

Adhikari, T., Biswas, A.K., Saha, J.K., 2005. Cadmium phytotoxicity in spinach with or without spent wash in a vertisol. Commun. Soil Sci. Plant Anal. 36, 1499-1511. http://dx. doi.org/10.1081/CSS-200058495.

Albanese, S., Sadeghi, M., Lima, A., Cicchella, D., Dinelli, E., Valera, P., Falconi, M. Demetriades, A., De Vivo, B., 2015. GEMAS: cobalt, Cr, Cu and Ni distribution in agricultural and grazing land soil of Europe. J. Geochem. Explor. 154, 81-93. http://dx.doi. org/10.1016/j.gexplo.2015.01.004.

Almeida, J.S., 2002. Predictive non-linear modeling of complex data by artificial neural networks. Curr. Opin. Biotechnol. 13, 72-76. http://dx.doi.org/10.1016/S09581669(02)00288-4

Alvarez, J.M., Lopez-Valdivia, LM., Novillo, J. Obrador, A, Rico, M.I, 2006. Comparison of EDTA and sequential extraction tests for phytoavailability prediction of manganese and zinc in agricultural alkaline soils. Geoderma 132, 450-463. http://dx.doi.org/10 1016/j.geoderma.2005.06.009.

Amiri, F., 2014. A nutritive value of Iranian mangrove ecosystems, northern part of the Persian Gulf. Nat. Resour. Res. 23, 321-330.

Arcega-Cabrera, F., Armienta, M.A., Daesslé, L.W., Castillo-Blum, S.E., Talavera, O., Dótor, A 2009. Variations of $\mathrm{Pb}$ in a mine-impacted tropical river, Taxco, Mexico: use of geochemical, isotopic and statistical tools. Appl. Geochem. 24, 162-171. http://dx.doi. org/10.1016/j.apgeochem.2008.09.015.

Arsenović, M., Radojević, Z., Stanković, S., Lalić, Ž., Pezo, L., 2013. What to expect from heavy clay? Ceram. Int. 39, 1667-1675. http://dx.doi.org/10.1016/j.ceramint.2012. 08.009 .

Ashraf, M.A., Maah, M.J., Yusoff, I., 2012. Chemical speciation and potential mobility of heavy metals in the soil of former tin mining catchment. ScientificWorldJournal 2012, 125608. http://dx.doi.org/10.1100/2012/125608.

Basheer, I., Hajmeer, M., 2000. Artificial neural networks: fundamentals, computing, design, and application. J. Microbiol. Methods 43, 3-31. http://dx.doi.org/10.1016 S0167-7012(00)00201-3.

Cornu, S., Deschatrettes, V., Salvador-Blanes, S., Clozel, B., Hardy, M., Branchut, S., Le Forestier, L., 2005. Trace element accumulation in Mn-Fe-oxide nodules of a planosolic horizon. Geoderma 125, 11-24. http://dx.doi.org/10.1016/j.geoderma. 2004.06.009.

de Matos, A.T., Fontes, M.P.F., da Costa, L.M., Martinez, M.A., 2001. Mobility of heavy metals as related to soil chemical and mineralogical characteristics of Brazilian soils. Environ. Pollut. 111, 429-435. http://dx.doi.org/10.1016/S0269-7491(00)00088-9.

Dimović, S., Smičiklas, I., Šljivić-Ivanović, M., Dojčinović, B., 2013. Speciation of 90Sr and other metal cations in artificially contaminated soils: the influence of bone sorbent addition. J. Soils Sediments 13, 383-393. http://dx.doi.org/10.1007/s11368-0120633-7.

FAO, 2006. World reference base for soil resources 2006. World Soil Resources Reports http://dx.doi.org/10.1017/S0014479706394902.

Giacomino, A. Abollino, O., Malandrino, M., Mentasti, E., 2011. The role of chemometrics in single and sequential extraction assays: a review. Part II. Cluster analysis, multiple linear regression, mixture resolution, experimental design and other techniques. Anal. Chim. Acta 688, 122-139. http://dx.doi.org/10.1016/j.aca.2010.12.028.

Gleyzes, C., Tellier, S., Astruc, M., 2002. Methodologies for soil and sediment fractionation studies. In: Quevauviller, P. (Ed.), Methodologies for soil and sediment fractionation studies, single and sequential extraction procedures. Royal Society of Chemistry, Cambridge, p. 200 http://dx.doi.org/10.1039/9781847551412.

Grieu, S., Faugeroux, O., Traoré, A., Claudet, B., Bodnar, J.-L., 2011. Artificial intelligence tools and inverse methods for estimating the thermal diffusivity of building materials. Energy Build. 43, 543-554. http://dx.doi.org/10.1016/j.enbuild.2010.10.020.

Guo, P., Xie, Z.L., Li, J., Kang, C.L., Liu, J.H., 2005. Relationships between fractionations of Pb, $\mathrm{Cd}, \mathrm{Cu}, \mathrm{Zn}$ and $\mathrm{Ni}$ and soil properties in urban soils of Changchun, China. Chin. Geogr. Sci. $15,179-185$.

He, Q., Ren, Y., Mohamed, I., Ali, M., Hassan, W., Zeng, F., 2013. Assessment of trace and heavy metal distribution by four sequential extraction procedures in a contaminated soil. Soil Water Res. 8, 71-76.

Kabata-Pendias, A., 2001. Trace Elements in Soils and Plants, Third Edition. third ed. CRC Press, Boca Raton, FL.

Kashani, M.H., Ghorbani, M.A., Dinpashoh, Y., Shahmorad, S., 2014. Comparison of Volterra model and artificial neural networks for rainfall-runoff simulation. Nat. Resour. Res. 23, 341-354.

Kelepertzis, E., Paraskevopoulou, V., Argyraki, A., Fligos, G., Chalkiadaki, O., 2015. Evaluation of single extraction procedures for the assessment of heavy metal extractability in citrus agricultural soil of a typical Mediterranean environment (Argolida, Greece). J. Soils Sediments 15, 2265-2275. http://dx.doi.org/10.1007/s11368-015-1163-x.

Lucho-Constantino, C.A., Alvarez-Suárez, M., Beltrán-Hernández, R.I., Prieto-García, F., Poggi-Varaldo, H.M., 2005. A multivariate analysis of the accumulation and fractionation of major and trace elements in agricultural soils in Hidalgo State, Mexico irrigated with raw wastewater. Environ. Int. 31, 313-323. http://dx.doi.org/10.1016/j. envint.2004.08.002.

Luz, F., Mateus, A., Matos, J.X., Gonçalves, M.A., 2014. Cu- and Zn-soil anomalies in the NE border of the South Portuguese Zone (Iberian Variscides, Portugal) identified by multifractal and geostatistical analyses. Nat. Resour. Res. 23, 195-215.

Martinez, C.E., McBride, M.B., 1998. Coprecipitates of $\mathrm{Cd}, \mathrm{Cu}, \mathrm{Pb}$ and $\mathrm{Zn}$ in iron oxides: solid phase transformation and metal solubility after aging and thermal treatment. Clay Clay Miner. 46, 537-545.

Nadaska, G., Lesny, J., Michalik, I., 2012. Environmental aspect of manganese chemistry. Hung. Electron. J. Sci. HEJ ENV-10, 1-16.

Navas, A., Lindhorfer, H., 2005. Chemical partitioning of Fe, Mn, Zn and $\mathrm{Cr}$ in mountain soils of the Iberian and Pyrenean ranges (NE Spain). Soil Sediment Contam. Int. J. 14, 249-259. http://dx.doi.org/10.1080/15320380590928311.

Pérez, G., Valiente, M., 2005. Determination of pollution trends in an abandoned mining site by application of a multivariate statistical analysis to heavy metals fractionation using SM\&T-SES. J. Environ. Monit. 7, 29-36. http://dx.doi.org/10.1039/b411316k.

Petrovic, D., Todorovic, M., Manojlovic, D., Krsmanovic, V.D., 2009. Speciations of trace metals in the accumulation Bogovina on the Crni Timok river. Pol. J. Environ. Stud. $18,873-884$.

Peverill, K., Sparrow, L., Reuter, D., 1999. Soil Analysis: An Interpretation Manual. CSIRO Publishing.

Pezo, L., Curcic, B., Filipovic, V., Nicetin, M., Koprivica, G., Misljenovic, N., Levic, L., 2013. Artificial neural network model of pork meat cubes osmotic dehydration. Hem. Ind. 67, 465-475. http://dx.doi.org/10.2298/HEMIND120529082P.

Pueyo, M., Sastre, J., Hernández, E., Vidal, M., López-Sánchez, J.F., Rauret, G., 2003. Heavy metals in the environment: prediction of trace element mobility in contaminated soils by sequential extraction. J. Environ. Qual. 32, 2054-2066.

Reiser, R., Simmler, M., Portmann, D., Clucas, L., Schulin, R., Robinson, B., 2014. Cadmium concentrations in New Zealand pastures: relationships to soil and climate variables. J. Environ. Qual. 43, 917-925. http://dx.doi.org/10.2134/jeq2013.09.0367.

Rezapour, S., Jafarzadeh, A.A., Samadi, A., Oustan, S., 2009. Impacts of clay mineralogy and physiographic units on the distribution of potassium forms in calcareous soils in Iran. Clay Miner. 44, 327-337. http://dx.doi.org/10.1180/claymin.2009.044.3.327.

Riba, I., Delvalls, T.a., Forja, J.M., Gómez-Parra, A., 2002. Evaluating the heavy metal contamination in sediments from the Guadalquivir estuary after the Aznalcóllar mining spill (SW Spain): a multivariate analysis approach. Environ. Monit. Assess. 77, 191-207. http://dx.doi.org/10.1023/A:1015828020313.

Sarkar, S.K., Favas, P.J.C., Rakshit, D., Satpathy, K.K., 2014. Geochemical speciation and risk assessment of heavy metals in soils and sediments. In: Hernandez-Soriano, M.C. (Ed.), Environmental Risk Assessment of Soil Contamination. InTech, p. 918 http://dx.doi. org/10.5772/57295.

Sipos, P., Németh, T., Choi, C., Szalai, Z., Balázs, R., 2014. Distribution, geochemical fractionation and sorption of $\mathrm{Cu}$ and $\mathrm{Pb}$ in soils characteristic of Hungary. Cent. Eur. Geol. 57, 265-285. http://dx.doi.org/10.1556/CEuGeol.57.2014.3.3.

Smičiklas, I., Jović, M., Šljivić-Ivanović, M., Mrvić, V., Čakmak, D., Dimović, S., 2015. Correlation of $\mathrm{Sr} 2+$ retention and distribution with properties of different soil types. Geoderma 253-254, 21-29. http://dx.doi.org/10.1016/j.geoderma.2015.04.003.

Sungur, A., Soylak, M., Ozcan, H., 2014. Investigation of heavy metal mobility and availability by the BCR sequential extraction procedure: relationship between soil properties and heavy metals availability. Chem. Speciat. Bioavailab. 26, 219-230. http://dx. doi.org/10.3184/095422914X14147781158674.

Taylor, B.J., 2006. Methods and Procedures for the Verification and Validation of Artificial Neural Networks. first ed. Springer US http://dx.doi.org/10.1007/0-387-29485-6.

Tessier, A., Campbell, P.G.C., Blsson, M., 1979. Sequential extraction procedure for the speciation of particulate trace metals. Anal. Chem. 51, 844-851.

Tokalioğlu, Ş., Kartal, Ş., 2003. Relationship between vegetable metal and soil-extractable metal contents by the BCR sequential extraction procedure: chemometrical interpretation of the data. Int. J. Environ. Anal. Chem. 83, 935-952. http://dx.doi.org/10.1080/ 03067310310001608740 . 
Tokalioğlu, S., Kartal, S., Güneș, A.A., 2004. Statistical evaluation of bioavailability of metals to grapes growing in contaminated vineyard soils using single extractants. Int. J. Environ. Anal. Chem. 84, 691-705. http://dx.doi.org/10.1080/03067310410001688444.

Torres, E., Auleda, M., 2013. A sequential extraction procedure for sediments affected by acid mine drainage. J. Geochem. Explor. 128, 35-41. http://dx.doi.org/10.1016/j. gexplo.2013.01.012.

US EPA, 2007. Method 3051: microwave assisted acid digestion of sediments, sludges, soils, and oils. Test Methods Eval. Solid Waste, pp. 1-30.
Walna, B., Spychalski, W., Ibragimow, A., 2010. Fractionation of iron and manganese in the horizons of a nutrient-poor forest soil profile using the sequential extraction method. Pol. J. Environ. Stud. 19, 1029-1037.

Yu, K.C., Chang, C.Y., Tsai, L.J., Ho, S.T., 2000. Multivariate analyses on heavy metal binding fractions of river sediments in Southern Taiwan. Water Sci. Technol. 42, 193-199. 